\title{
Analisis Perkembangan Kota Pagar Alam Masa Walikota Ida Fitriati Tahun 2013- 2017
}

\author{
Jeli Miranti, Supriyanto, Alian Sair \\ Program Studi Pendidikan Sejarah, FKIP, Universitas Sriwijaya
}

\begin{abstract}
Abstrak
Suatu kota bisa berkembang tidak terlepas dari peran kepala daerah yang ada dengan tujuan pembangunan yang merata. Hal itu dapat dilihat dari beberapa indikator penunjang yang membantu terwujudnya dari perkembangan kota tersebut. Pada penelitian yang berjudul Analisis Perkembangan Kota Pagar Alam Pada Tahun 20132017 mempunyai beberapa rumusan masalah antara lain peran Walikota Ida Fitriati dalam perkembangan Kota Pagar Alam, analisis perkembangan ekonomi Kota Pagar Alam, analisis angka kemiskinan Kota Pagar Alam, analisis jumlah pengangguran dan angkatan kerja Kota Pagar Alam dan analisis Indeks Pembangunan Manusia Kota Pagar Alam pada tahun tersebut. Penelitian ini bertujuan untuk mengetahui bagaimana proses perkembangan Kota Pagar Alam tersebut pada setiap tahunnya dalam bentuk. Adapun penelitian tersebut menghasilkan beberapa hasil antara lain dari ke empat indikator yang disebutkan hanya indiKator Indeks Pembangunan Manusia yang mengalami kemunduran dari 5 tahun sebelumnya padahal Kota Pagar Alam memiliki penduduk miskin paling sedikit di Provinsi Sumatera Selatan. Padahal seharusnya kedua hal tersebut saling mengimbangi satu sama lain.
\end{abstract}

Kata Kunci: Ida Fitriati, Kota, Pagar Alam

\section{Pendahuluan}

Sumatera Selatan merupakan salah satu provinsi yang terdapat di Indonesia yang berdiri tanggal 12 September 1950. Sumatera Selatan memiliki wilayah dengan luas keseluruhan mencapai 87.017,41 km² dan dengan sumber daya alam yang melimpah hampir di setiap daerahnya. Sehingga setiap kabupaten dan kota mampu memenuhi kebutuhannya sendiri.

Posisi Provinsi Sumatera Selatan yang seperti ini mendukung terjadinya perkembangan pesat di setiap kabupaten kota yang berada di dalamnya (Badan Pusat Statistik Sumatera Selatan, 2017). Jumlah kabupaten/kota pada tahun 1995 di Sumatera Selatan hanya 8 Kabupaten dan 2 kota madya (Hanifah, 1995: 9). Namun pada tahun 2013 sudah berkembang menjadi 11 kabupaten dan 4 kota Madya (Badan Pusat Statistik Kota Pagar Alam, 2013: 265). Proses perkembangan daerah tersebut sejalan dengan adanya Peraturan Pemerintah 129 tahun 2000 tentang persyaratan, pembentukan daerah, penghapusan dan pembangunan daerah.

Peraturan pemerintah tersebut
dimanfaatkan oleh daerah untuk mengemukakan gagasan terhadap pemekaran daerahnya, selama daerah tersebut telah memenuhi persyaratan yang telah diberlakukan. Persyaratan tersebut meliputi syarat teknis antara lain kemampuan ekonomi, sosial, budaya, sosial politik, kependudukan luas daerah, pertahanan dan keamanan. Tujuan dari 
pemekaran daerah tersebut adalah untuk mempermudah tahapan pembangunan yang terpencar dari di seluruh wilayah (Kusuma, 2017: 3). Adanya perkembangan daerah yang dipimpin oleh pemerintah lokal sangat penting dalam kemajuan demokrasi negara. Karena pemerintah lokal dianggap lebih dekat dengan masyarakat dan mampu melihat apa saja yang menjadi kebutuhan pokok di dalam masyarakat.

Hal tersebut bertujuan untuk membuat daerah yang telah berkembang tersebut menjadi lebih stabil, merangsang dan meningkatkan proses pembangunan ekonomi di wilayah itu, dan melibatkan masyarakat dalam proses pembangunan wilayah tersebut (Moisiu, 2013: 460). Awalnya Kota Pagar Alam merupakan sebuah kecamatan bergabung dengan Kabupaten Lahat. Dengan beberapa alasan melepaskan diri dari kabupaten induknya. Sehingga sesuai Undang-Undang Republik Indonesia Nomor 8 tahun 2001 tanggal 21 Juni 2001 Dewan Perwakilan Rakyat Republik Indonesia (DPR RI) menetapkan tentang pembentukan Kota Pagar Alam sebagai kota otonom dengan berbagai pertimbangan yang ada.

Sesuai dengan prinsip dan persyaratan berdirinya kota otonom, Pagar Alam dapat memenuhi semua persyaratan tersebut, termasuk dalam urusan pendanaan. Sehingga diputuskan bahwa Pagar Alam resmi dibentuk sebagai kota otonom yang disetujui oleh Dewan
Perwakilan Rakyat Republik Indonesia, dengan beberapa Kecamatan dan berbatasan langsung dengan Kabupaten Lahat, Jarai, Tanjung Sakti dan Kota Agung. Pada 12 November 2001 ditetapkan Djazuli Kuris oleh Gubernur Provinsi Sumatera Selatan atas nama Menteri Dalam Negeri sebagai pejabat sementara Walikota Pagar Alam (Mahardika dan Fajri. 2013: 20).

Berlanjut setelah itu, Djazuli Kuris menjadi walikota selama 2 periode di Kota Pagar Alam dengan wakilnya yang kedua adalah Ida Fitriati. Selanjutnya setelah menjadi wakil wali kota, Ida Fitriati mencalonkan diri dan terpilih menjadi walikota Pagar Alam periode 2013-2018. Ida Fitriati merupakan seorang perempuan yang mempunyai keahlian dibidang kesehatan yang mampu terjun ke dunia politik. Selain itu, Ida Fitriati merupakan kepala daerah perempuan pertama di Sumatera Bagian Selatan (Portal Rakyat Merdeka Online Sumsel, 2014 dan Repulika.co.id, 2014).

Walaupun sebenarnya keterlibatan aktif perempuan Indonesia dibidang politik sudah ada sejak zaman pergerakan, yang saat itu mereka mampu membangkitkan kesadaran dan rasa nasionalisme di kalangan perempuan itu sendiri (Abraham Nurcahyo, 2016: 25). Pada kepemimpinan Ida Fitriati selama 5 tahun, program pembangunan yang dilakukan sebagian merupakan lanjutan dari program walikota sebelumnya. Namun hasil yang dicapai dari 
beberapa indikator mengalami peningkatan pesat dari periode sebelumnya. Meskipun ada faktor yang sebaliknya. Sehingga perkembangan Kota Pagar Alam periode ini dapat diperhitungkan.

\section{Tinjauan Pustaka}

\section{A. Pengertian Perkembangan Kota}

Menurut Departeman Dalam Negeri mendefinisikan kota sebagai pusat pemukiman dan kegiatan penduduk yang mempunyai batasan wilayah administrasi yang diatur dalam peraturan perundangundangan, serta pemukiman yang telah mencerminkan watak dan ciri kehidupan perkotaan. Sedangkan untuk pusat kota mempunyai pengertian yang berbeda yaitu Urban Center atau pusat penduduk. Terkadang juga diartikan sebagai pusat pemerintahan di daerah atau Civic Center, yang secara otomatis terdapat pula daerah yang disebut dengan pinggiran kota.

Semua yang telah disebutkan tadi tentu saja mengacu pada perkembangan kota itu sendiri (Damayanti dan Handinoto, 2005: 34). Menurut Geddes, kota merupakan suatu wadah yang di dalamnya terdapat suatu skema dasar yang dalam proses perkembangan yang memiliki pekerjaan dasar dalam suatu konteks environment (Young dan Clavel, 2017: 40). Secara umum, kota dapat diartikan sebagai suatu wilayah mempunyai batas-batas wilayah yag jelas, di dalamnya terdapat kelompok masyarakat yang hidup dipengaruhi oleh situasi dan kondisi dari wilayah tersebut. Setelah di analisis dalam perkembanganan kota, terdapat beberapa faktor yang berpengaruh antara lain proses perkembangan dan pertumbuhan kota, faktor pendukung, sehingga terdapat suatu struktur yang disusun dalam pelaksanaan perkembangan kota tersebut. Adapun yang berpengaruh dalam proses perkembangan kota adalah letak geografis, keadaan topografi, bagaimana kota tersebut di fungsikan, kebudayaan, akses jalan dan unsur pendukung umum lain (Hartono, dkk, 2014: 77-78).

B. Peranan

Wanita

dalam

Perkembangan

Suatu hal yang jarang jika membicarakan tentang peran perempuan dalam dalam perkembangan dan sejarah. Karena dalam penulisan suatu sejarah biasanya tentang politik dan militer, dengan mempunyai tema fokus pada suatu titik. Sehingga peran wanita dapat dilihat dari beberapa sudut pandang yang berbeda. Meskipun hanya menjadi pandangan kedua. Sudut pandang gender juga mempengaruhi terkait penilaian di dalam masyarakat tentang perilaku dan kepribadian seseorang perempuan (Hanif, 2011: 66).

Peranan laki-laki dan perempuan itu berbeda. Ada yang berpendapat bahwa perbedaan tersebut berdasarkan ciri fisik yang tamoak dari diri seseorang yeng lemah dan diliputi ketidakberdayaan, sehingga peran perempuan dan laki-laki itu berbeda. Sehingga kedudukan gender di masyarakat 
sangat diutamakan. Namun dalam perkembangannya, sekarang kedudukan perempuan sudah mampu disetarakan dengan kedudukan laki-laki baik itu pada bidang sosial, ekonomi dan politik (Norfia Eka Praesti dan Novi Triana Habsari, 2013: 131). Pernyataan lain antara lain suatu kegiatan yang mengarah pada membangun suatu pergerakan strategi politik untuk mengintimidasi perempuan bukan menuliskan peranan perempuan pada umumnya dalam kehidupan sosial, budaya dan politik (Muhammad Hanif, dkk, 2011: 163).

Namun pada perkembangannya peran perempuan sudah berbeda dari sebelumnya. Perempuan sudah berpartisipasi dalam politik. Menurut Herbert McClosky, partisipasi politik ialah kegiatan yang mereka lakukan untuk menanamkan peran dalam kekuasaan di masyarakat baik langsung atau tidak langsung dan berpengaruh dalam kebijakan umum.

Sehingga Pasal 27 ayat 1 UUD Negara Republik Indonesia menyebutkan adanya kesetaraan antara Laki-Laki dan perempuan sebagai warga negara. Sehingga kebijakan mengenai peremuan sudah ditetapkan pada pemilu 1999 bahwa di dalam partai politik harus memperhatikan keadilan gender. Maksudnya di sini adalah arus sesuai pembagiannya antara laki-laki dan perempuan (Abraham Nurcahyo, 2016: 28-29).
Metode Penelitian

\section{A. Metode dan Jenis Penelitian}

Sesuai dengan masalah yang telah diajukan sebelumnya, dalam proses penelitian data yang di dapat adalah data yang berbentuk kata-kata, dan proses dilapangan akan penelitian ini merupakan penelitian historis. Metode historis adalah prosedur pemecahan masalah dengan menggunakan data masa lalu atau peninggalan-peninggalan, baik untuk memahami kejadian atau suatu keadaan yang berlangsung pada masa lalu dan dalam kaitannya dengan kejadian masa sekarang.

Tujuan menggunakan metode historis adalah untuk menggambarkan masa lampau secara sistematis dan obyektif, dengan cara mengumpulkan, evaluasi dan verifikasi bukti untuk mendapatkan fakta dan kesimpulan. Jenis penelitian ini adalah deskriptif dengan mengungkapakan data yang di dapat di lapangan sesuai dengan hal yang terjadi (fakta).

\section{B. Teknik Pengumpulan Data}

\section{Studi Pustaka}

Studi kepustakaan adalah proses mencari sumber dengan mengunjungi berbagai perpustakaan, adapun dalam penelitian ini peneliti mengunjungi beberapa perpustakaan, dintaranya: Ruang Baca FKIP Unsri, perpustakaan pusat Universitas Sriwijaya, perpustakaan wilayah Propinsi Sumatera Selatan, Perpustakaan Daerah Kota Pagar Alam, Badan Pusat Statistik daerah Pagar 
Alam, dan perpustakaan Museum Balaputra Dewa. Serta adanya bantuan data dari beberapa dinas terkait dengan penelitian seperti Badan Humas dan Protokol Kota Pagar Alam, Badan Pusat Statistik Kota Pagar Alam Badan Perpustakaan dan Arsip Daerah Kota Pagar Alam dan Badan Perencanaan dan Pembangunan Daerah Kota Pagar Alam.

Setelah dilakukan studi pustaka maka akan didapat beberapa jenis sumber. Sumber dalam penelitian sejarah berupa sumber primer maupun sumber sekunder. Sumber primer adalah bukti sejarah tangan pertama yang dibuat pada saat kejadian terjadi oleh seseorang yang ditunjukkan atau ditampilkan kepada peristiwa. sedangkan sumber tambahan adalah karya berdasarkan sejarah yang dibuktikan dari sumber utama. Seperti deklarasi atau kesaksian yang diberikan oleh seseorang atau sekelompok orang (Irwanto dan Sair, 2014 : 57-58).

\section{Wawancara}

Setelah mendapatkan data dari berbagai sumber, peneliti melakukan wawancara terhadap tokoh yang terkait dengan data tersebut untuk mengklarifikasi apakah data tersebut adalah benar dan sesuai dengan yang terjadi dilapangan. Menurut Bungin (2013: 133), metode wawancara juga bisa diklaim sebagai metode interview. Metode wawancara adalah proses memperoleh informasi buat tujuan penelitian dengan cara tanya jawab sambil bertatap muka antara pewawancara menggunakan responden atau orang yang diwawancarai menggunakan atau tanpa menggunakan pedoman wawancara. Inti asal metode wawancara ini bahwa di setiap penggunaan metode selalu timbul beberapa hal yaitu pewawancara, responden, materi wawancara dan pedoman wawancara.

Untuk memperoleh data yang dapat dipertanggungjawabkan, dilaksanakan personal dengan orang yang diwawancarai yaitu dengan kedua tokoh walikota pada lingkup tahun yang telah ditentukan yaitu Ida Fitriati juga dilakukan wawancara dengan orang terdekat yang memiliki keterkaitan dan juga pengetahuan mengenai topik dan tema yang telah dipilih.

\section{Kritik Sumber}

Pembuktian penelitian sejarah identik dengan kritik sumber, yaitu kritik eksteren untuk mencari otentisitas atau keotentikan (keaslian) sumber, serta kritik interen yang menilai apakah sumber itu dapat dipercaya atau tidak (Priyadi, 2014: 62). Penelitian merupakan usaha untuk mencari kebenaran dengan cara membedakan apa yang benar dan yang salah, apa yang menjadi mungkin dan tidak mungkin, sehingga di dapat data yang sebenarnya dalam penulisan sejarah 
(Sjamsuddin, 2007: 131). Pada penulisan hasil penelitian sangat diperlukan untuk melakukan kritik sumber yang berhasil di dapat dan dikumpulkan untuk mendapatkan sumber yang dapat dipertanggung jawabkan. Kritik sumber dibagi menjadi dua yaitu kritik eksteren dan kritik interen.

\section{Kritik Eksteren}

Pembuktian penelitian sejarah identik dengan kritik sumber, yaitu kritik eksteren untuk mencari otentisitas atau keotentikan (keaslian) sumber serta kritik interen yang menilai apakah sumber itu dapat dipercaya atau tidak (Priyadi, 2014: 62). Penelitian merupakan usaha untuk mencari kebenaran dengan cara membedakan apa yang benar dan yang salah, apa yang menjadi mungkin dan tidak mungkin sehingga didapatlah data yang sebenarnya dalam penulisan sejarah (Sjamsuddin, 2007: 131).

\section{Kritik Intern}

Setelah dilakukan kritik eksteren untuk mengetahui tentang keaslian dari sumber tersebut barulah dapat dilakukan kritik interen. Tujuan dari kritik intern yaitu untuk menentukan tingkat kebenaran isi atau informasi dari sumber yang akan digunakan. Umpan balik dari dalam ini adalah tahap pengaturan di mana memilih dari informasi apakah kebenaran dan presisi serta dapat dipertanggungjawabkan (Nawawi, 2012: 86). Seseorang peneliti sejarah pertama kali mengusut kesaksian menggunakan jalan dengan memperoleh seperangkat unsur yang relevan bagi topik masalah yang ada dalam masalah. Kritik interen berkaitan dengan problem kredibilitas asal sumber, apakah bisa dianggap atau tidak. Oleh karena itu, kritik interen lebih banyak membahas tentang narasi yang disampaikan dalam sumber tadi. Untuk menghindari subjek hiperbola asal pengarang terhadap data yang dibutuhkan penulis, maka berusaha buat mengkritisi dan membandingkannya.

Hal ini dilakukan guna mendapatkan data yang valid sehingga bisa menyajikan informasi yang sebaik serta sesubyektif mungkin (Irwanto dan Sair, 2014: 84). Dalam buku Besemah dalam Lintasan Sejarah berisi mengenai sejarah dan adatadat besemah. Buku ini sedikit banyak mempunyai keterkaitan dengan bahasan yang dipilih. Buku Antakkah Lemak Nanggung Kuday merupakan buku yang berisi tentang kehidupan masa kecil tokoh Djazuli Kuris hingga beliau menjabat sebagai walikota Pagar Alam. Buku lainnya yaitu buku yang dibuat untuk mengenang pengabdian dari tokoh Djazuli Kuris selama beliau menjabat sebagai walikota.

Tedapat juga tulisan tentang Ida Fitriati yang terdapat di artikel-artikel internet. Sumber tersebut ada yang berasal dari Badan Pengurus Daerah Kota Pagar Alam dan koran lokal Pagar Alam yang mewawancarai beberapa penduduk Kota Pagar Alam yang merasakan beberapa 
dampak baik kebijakan yang dilakukan oleh walikota Ida Fitriati.

\section{Interpretasi}

Pada tahap ini data atau fakta yang telah diperoleh perlu dihubungkan dengan bukti dan dikaitkan satu sama lain. Sehingga antara fakta dengan fakta lain terlihat sebagai rangkaian yang masuk akal. Menurut Suyanti dan Sutina (2005: 140), interpretasi adalah menetapkan makna dan saling menghubungkan antara fakta yang diperoleh. Interpretasi diperlukan agar data yang mati dapat berbicara atau mempunyai arti. Suatu peristiwa sejarah bisa ditafsirkan ulang oleh orang lain, dari sudut pandang mana seseorang melihat suatu peristiwa.

Dalam melihat rangkaian fakta ini menyebabkan penulis harus untuk melakukan interpretasi data. Sehingga tidak semua fakta dimasukkan ke dalam tulisan, melainkan data yang mempunyai informasi relevan. Interpretasi juga disebut analisis sejarah. Analisis berarti menguraikan secara terminologi yang berbeda dengan sintensis yang menyatukan. Di mana analisis dan sintesis ini dipandang sebagai metodemetode utama dalam interpretasi.

Data mentah yang telah dikumpulkan oleh peneliti tidak akan ada gunanya jika tidak di analisa. Analisa data merupakan bagian yang penting dalam metode ilmiah. Karena dengan analisa data tersebut dapat diberi arti dan makna yang berguna dalam memecahkan masalah penelitian. Data mentah yang telah dikumpulkan perlu dipecahkan dalam kelompok-kelompok, diadakan kategorisasi, dilakukan manipulasi serta diperas sedemikian rupa, sehingga data tersebut mempunyai makna untuk menjawab masalah dan bermanfaat untuk menguji hipotesa (Nazir, 1988: 405).

\section{E. Historiografi}

Historiografi adalah hal-hal yang berkaitan dengan ilmu sejarah dalam praktiknya. Seperti contoh bentuk atau gambar berdasarkan informasi dan sumber yang ada. Dalam penerapannya makna disebut sebagai metodologi dari sejarah itu. Teknik ini menggambarkan langkahlangkah yang di dasari pada pengelompokan klarifikasi dari peristiwa itu sendiri (Irwanto dan Sair, 2014: 151).

\begin{tabular}{rrr}
\multicolumn{2}{c}{ Metodologi juga menuliskan } \\
bagaimana peristiwa dijelaskan
\end{tabular}
menggunakan narasi, interpretasi, pandangan umum dan bukti. Penulisan sejarah dapat digunakan untuk berkomunikasi terhadap data-data hasil penelitian yang telah terungkap, dicoba (dikonfirmasi) dan diterjemahkan. Jika pertanyaan otentik tentang poin untuk membuat kembali sejarah yang ada di masa lalu, maka rekonstruksi peristiwa telah menjadi skala pada saat penulisan disusun (Daliman, 2018: 89).

Penulisan sejarah penting dalam mempertimbangkan aspek dari urutan peristiwa sejarah. Oleh karena jika tidak berurutan akan menjadi membingungkan. 
Peristiwa sejarah disusun menggunakan sebab akibat. Sehingga jalan ceritanya lengkap diterima oleh para pembacanya. Dengan demikian, dalam penulisan diupayakan agar menyajikan hasil dari data dan sumber dengan sebaik mungkin, serta menuliskan data yang diperoleh secara lengkap sesuai dengan aturan penulisan yang berlaku, sehingga tulisan dapat dipertanggungjawabkan.

\section{F. Pendekatan}

Pendekatan adalah titik pandang yang digunakan untuk menyelidiki dan berbicara tentang suatu masalah. Sehingga dapat diputuskan dengan cara menganalisis masalah dan menjadi garis permulaan dalam menyelidiki masalah tersebut. Pendekatan merupakan bagaimana kita memandang masalah tersebut dengan sudut pandang kita sendiri (Kartodirjo, 1993: 4).

Dalam penulisan peristiwa yang terjadi biasanya terdapat pendekatan. Pendekatan ini adalah pengkategorian dari penulisan penelitian. Sehingga semua yang ditulis mempunyai keterkaitan satu sama lain, berdasarkan sudut pandang mana melihatnya. Penulisan penelitian ini menggunakan pendekatan multidisiplin ilmu dari ilmu sosial meliputi pendekatan ilmu ekonomi, pendekatan ilmu politik dan pendekatan ilmu sosiologi.

\section{Pendekatan Ekonomi}

Masalah ekonomi bisa menjadi pendorong dalam sejarah. Setiap hal yang terkait dengan kerangka kerja sosial, politik dan kebudayaan lebih sering berhubungan dengan kerangka kerja ekonomi yang ada. Sebagai aturan dalam struktur komunitas atau masyarakat, hal yang dapat mengubah premis sosial adalah kerangka sistem ekonomi (Irwanto dan Sair, 2014: 120).

Kota adalah susunan kehidupan manusia yang ditandai oleh kepadatan kehidupan manusia yang dicirikan oleh populasi yang tinggi, dan di warnai oleh kepadatan populasi yang tinggi, dan diwarnai oleh strata sosial ekonomi materialistis. Atau dapat diterjemahkan sebagai adegan sosial yang disebabkan oleh unsur alami dan komponen nonalami dengan efeknya yaitu adanya indikasi konsentrasi penduduk (Hariyono, 2007: 14).

\section{Pendekatan Politik}

Politik menyiratkan kecerdasan dan kebijaksanaan, yang dalam kehidupan sehari-hari menganggapnya sebagai cara untuk mewujudkan tujuan. Permulaan kata politik itu sendiri berasal dari kata pengaturan yang menunjukkan keadaan negara atau polis. Masalah politik menyiratkan bahwa ada hubungan yang luar biasa antara orang yang hidup bersama, dalam hubungan itu muncul aturan, spesialis, perilaku resmi, kontrol legitimasi dan pada akhirnya kekuasaan.

Masalah politik juga dapat diartikan sebagai kelihaian, kualitas, kontrol pemerintah, mengontrol perselisihan 
menjadi perjanjian nasional, dan setelah itu kontrol masyarakat (Syafiie, 2005: 47). Politik merupakan sejarah masa sekarang dan sejarah merupakan bagian dari politik masa lampau. Memang sudah ditegaskan sejarah memiliki keterkaitan dengan politik. Ada pula yang berpendapat bahwa sejarah ditulis oleh pemerintahan penguasa yang menjabat masa itu. Keduanya memperlihatkan keterlibatan satu sama lain.

Karena dalam perjalanannya, sejarah kebanyakan menuliskan tentang peranan tokoh dan kekuasaan (Kartodirdjo, 1992: 149). Pendekatan politik bertujuan untuk menyoroti bagaimana perkembangan pemerintahan dan masyarakat Kota Pagar Alam baik masa pemerintahan Djazuli Kuris dan Ida Fitriati. Bagaimana beliau menjadi abdi masyarakat dengan pelayanan kepengurusan yang menimbulkan kepuasan pribadi dari masyarakat.

\section{Hasil Dan Pembahasan}

\section{A. Peranan Ida Fitriati dalam \\ Perkembangan Kota Pagar Alam}

Peran dari Ida Fitriati terhadap perkembangan Kota pagar Alam tidak terlepas dari kedudukannya sebagai Walikota Pagar Alam Tahun 2013-2018 tersebut. Selain itu, beliau pada periode sebelumnya merupakan Wakil Walikota Pagar Alam dengan Djazuli Kurus selaku Walikota Pagar Alam. Keputusan Ida Fitriati untuk menjadi Kepala daerah bermula pada ajakan Djazuli Kuris pada tahun 2008 maju dalam pilkada tahun tersebut. Sehingga setelah periode tersebut Ida Fitriati merasa mencintai Kota pagar Alam dan ingin melanjutkan pembangunan yang lakukan. Akhirnya beliau maju sebagai Walikota Pagar Alam tahun 2013 yang didukung oleh suaminya (Wawancara Ida Fitriati, 7 Januari 2019). Untuk visi dan misinya sebagian melanjutkan dari sebelumnya. Yang membedakan adalah Ida Fitriati lebih untuk menambah kuantitas penghasilan pada bidang terkait.

Hal tersebut dibuktikan dengan adanya visi yaitu terwujudnya keseimbangan masyarakat Pagar Alam yang sehat, cerdas, berakhlaq mulia, dan di dukung oleh ekonomi kerakyatan yang tangguh dalam lingkungan yang alam (Pemerintah Kota Pagar Alam, 2017: II.1). Ida Fitriati mempunyai peran penting dalam perkembangan Kota pagar Alam pada periode tersebut.

Sebab selaku kepala daerah beliau melakukan usaha-usaha yang dilakukan dalam wujud visi dan di realisasikan dalam misi. Sehingga dalam perkambanganya Kota Pagar Alam sebagian besar atas perencanaan yang di lakukan oleh Ida Fitriati tersebut bersama dengan Satuan Kerja Perangkat Daerah yang terkait. Selain itu juga atas keberhailan dari Ida Fitriati dalam proses perkembagan Kota Pagar Alam beliau banyak menerima penghargaan 
yang terkait. Beberapa contoh penghargaan yang diperoleh diantaranya Penghargaan Wahana Tata Nugraha (WTN) tanggal 31 Januari 2017 di Istana Wakil Presiden yang diserahkan Wakil Presiden kepada Wakil Walikota Pagar Alam, Piagam Anugerah Perencanaan Terbaik (PANGRIPTA SRIWIJAYA) Tahun 2016, sebagai Kabupaten/Kota TERBAIK II dalam Penyusunan Rencana Kerja Pemerintah Daerah Tahun 2016 yang diserahkan oleh Gubernur Sumatera Selatan kepada Walikota Pagar Alam dan pada Tahun 2017, Kota Pagar Alam menerima Piagam Anugrah Perencanaan Terbaik (PANGRIPTA SRIWIJAYA) sebagai Kota TERBAIK I dalam Penyusunan Rencana Kerja Pemerintah Daerah Tahun 2017 yang diserahkan oleh Gubernur Sumatera Selatan kepada Walikota Pagar Alam, Piala Adipura Buana Tahun 2016 diterima oleh Pemerintah Kota Pagar Alam dari Kementerian Lingkungan Hidup tanggal 22 bulan Juli tahun 2016 yang diserahkan oleh Wakil Presiden Republik Indonesia kepada Walikota Pagar Alam,

\section{Penghargaan Manggala Karya}

Kencana dibidang Keluarga Berencana dari BKKBN Republik Indonesia pada tanggal 20 Juli 2016 yang diserahkan langsung oleh Kepala BKKBN RI kepada Walikota Pagar Alam, Penghargaan Anugerah Gemilang Penyiaran kategori program-program penyiaran terbaik se Sumatera Selatan tahun 2016, Penghargaan Adiwiyata Tingkat Provinsi Sumatera Selatan dari Gubernur
Sumatera Selatan, dan Juara II Stand Terbaik Pameran Pariwisata Tingkat Nasional di JJC Jakarta.

\section{B. Perkembangan Ekonomi Kota Pagar} Alam Tahun 2013-2017

Perkembangan suatu daerah tidak terlepas dari laju pertumbuhan ekonomi dari daerah tersebut. Perekonomian tersebut bisa didapat dari berbagai sektor baik kebijakan pemerintah atau perekonomian yang berputar di masyarakat. Perekonomian suatu daerah juga dapat dipengaruhi oleh nilai tukar rupiah ke mata uang asing, adanya krisis, ataupun hubungan dengan wilayah lain.

Pengembangan ekonomi Kota Pagar Alam dilakukan oleh pemerintah untuk menunjang peningkatan taraf hidup masyarakat, dan membuat perekonomian masyarakat menjadi meningkat dan merata. Pendapatan daerah juga dapat menunjang kemajuan perekonomian provinsi itu sendiri. Sehingga dalam pelaksanaannya, pengembangan perekonomian setiap kabupaten/kota berpacu pada target yang ditentukan oleh provinsi (Badan Pusat Statistik Kota Pagar Alam, 2018: 3).

Untuk mengetahui tingkat perkembangan perekonomian masyarakat perlu juga diketahui pendapatan regional berkala. Agar dapat digunakan sebagai acuan dalam perkembangan ekonomi. Perkembangan ekonomi berdasarkan presentase Produk Domestik Bruto Kota Pagar Alam berdasarkan lapangan usaha 
seperti sekor pertanian, perdagangan, penyediaan jasa, gas dan listrik, dan sebagainya. Pada Tabel tersebut menjelaskan beberapa faktor yang mendukung dari proses perkembangan ekonomi di Kota Pagar Alam. Tabel tersebut dijelaskan bahwa penghasil pendapatan asli daerah yang utama di Kota Pagar Alam selama periode 5 tahun yang paling tinggi adalah tahun 2013 yaitu 25,45\% adalah sektor pertanian, kehutanan, dan perikanan. Pada tahun 2017, sektor pertanian masih memegang peran penting dalam presentase Produk Domestik Regional Bruto namun paling rendah dalam periode 5 tahun yang mencapai $23,14 \%$.

Penurunan pada bidang pertanian, kehutanan dan perikanan ini dipengaruhi oleh banyak lahan pertanian dibuka sebagai pemungkiman masyarakat sehingga berkurang. Akhirnya luas lahan yang bisa digunakan menurun dan perkembangan harga pada sektor pertanian ini mempunyai peluang yang kecil untuk naik sehingga masyarakat ada yang pindah bekerja pada sektor lain.

Sedangkan pertumbuhan yang paling rendah adalah bagian Pengadaan listrik dan gas di Kota Pagar Alam. Sejak tahun 2013 hingga tiga tahun setelahnya perkembangan bidang ini hanya mengalami $0,3 \%$ dan tahun selanjutnya meningkat menjadi $0,4 \%$. Hal tersebut terjadi karena Kota Pagar Alam merupakan daerah yang bukan penghasil gas. Namun di daerah tertentu mempunyai sumber aliran listrik sendiri dengan menggunakan tenaga air. Sehingga walaupun tidak banyak mengalami kemajuan pada periode tersebut. Berikut merupakan perbandingan antara Produk Domesik Regional Bruto antara anggaran tahun terakhir antara walikota Djazuli Kuris tahun 2012 dan Ida Fitriati tahun 2017 berdasarkan beberapa bidang pekerjaan:

\begin{tabular}{|c|c|c|c|}
\hline No & Sektor & 2012* & $2017^{* *}$ \\
\hline 1 & Pertanian & 410.778 & $514.852,2$ \\
\hline 2 & $\begin{array}{l}\text { Pertambangan } \\
\text { dan Penggalian }\end{array}$ & 24.837 & $49.931,1$ \\
\hline 3 & $\begin{array}{l}\text { Industri } \\
\text { Pengolahan }\end{array}$ & 20.787 & $26.204,6$ \\
\hline 4 & $\begin{array}{l}\text { Listrik, Gas dan } \\
\text { Air Bersih }\end{array}$ & 2.747 & $1.045,1$ \\
\hline 5 & $\begin{array}{l}\text { Bangunan atau } \\
\text { Kontruksi }\end{array}$ & 279.588 & $366.758,6$ \\
\hline 6 & $\begin{array}{l}\text { Perdagangan, } \\
\text { Hotel dan } \\
\text { Restoran }\end{array}$ & 378.443 & $388.277,6$ \\
\hline 7 & $\begin{array}{l}\text { Pengangkutan } \\
\text { dan } \\
\text { Komunikasi }\end{array}$ & 162.225 & $156.600,5$ \\
\hline 8 & $\begin{array}{l}\text { Keuangan, } \\
\text { Persewaan/real } \\
\text { estate dan Jasa } \\
\text { Perusahaan }\end{array}$ & 95.362 & $208.984,3$ \\
\hline 9 & Jasa-jasa & 257.760 & $289.307,6$ \\
\hline
\end{tabular}
Sumber: *Pemerint. Kota Pagar Alam 2013: II-2 **Badan Pusat Statistik Kota Pagar Alam, 2018: 131

Pada tabel tersebut dijelaskan ada beberapa bidang pekerjaan yang menunjang Produk Domestik Regional Bruto di Kota Pagar Alam. Adapun perbandingan Anggaran Pendapatan Belanja Daerah Kota Pagar Alam pada masa Ida Fitriati dengan Djazuli Kuris pada periode sebelumnya antara lain: 
Tabel 2: Anggaran Pendapatan Belanja Daerah Kota Pagar Alam Tahun 2008-2012

\begin{tabular}{clc}
\hline No & Tahun & APBD \\
\hline 1 & 2008 & Rp.431.720.712.000,00 \\
2 & 2009 & Rp.385.359.212.491,00 \\
3 & 2010 & Rp.436.447.157.108,00 \\
4 & 2011 & Rp.491.209.572.745,00 \\
5 & 2012 & Rp.532.646.885.512,00 \\
\hline
\end{tabular}

Sumber: Pemerintah Kota Pagar Alam, 2013: III.7

$$
\text { Pada tahun } 2008 \text { Anggaran }
$$

Pendapatan dan Belanja Daerah Kota Pagar Alam mencapai Rp.431.720.712.000,00. Namun tahun 2009 mengalami penurunan yang sangat drastis yaitu Rp.385.359.212.491,00 hingga pada tahun selanjutnya mengalami peningkatan yang positif.

Tabel 3: Anggaran Pendapatan dan Belanja Daerah Tahun 2013-2017

\begin{tabular}{ccc}
\hline No & Tahun & APBD \\
\hline 1 & 2013 & Rp.633.688.770.648,00 \\
2 & 2014 & Rp.852.403.127.064,00 \\
3 & 2015 & Rp.816.005.973.572,00 \\
4 & 2016 & Rp.874.003.600.776,20 \\
5 & 2017 & Rp.888.544.891.456,23 \\
\multicolumn{2}{c}{ Jumlah } & Rp.4.064.646.363.516,43
\end{tabular}

Sumber: Pemerintah Kota Pagar Alam, 2017: III.5

Pada rentang 5 tahun tersebut Anggaran Pendapatan dan Belanja Daerah Kota Pagar Alam mengalami peningkatan yang pesat. Tahun 2013 hanya mencapai Rp.633.688.770.648,00 dan mengalami kenaikan pada tahun selanjutnya mencapai Rp.852.403.127.064,00. Namun pada tahun 2015 mengalami penurunan hingga mencapai Rp.816.005.973.572,00. Sehingga akhirnya pada tahun berikutnya kembali meningkat. Pada perbandingan Anggaran Pendapatan dan Belanja Daerah Kota Pagar Alam antara tahun 2008-2012 yang pada saat itu dipimpin Djazuli Kuris, dan tahun 2013-2017 yang dipimpin Ida Fitriati jelas mengalami kemajuan pesat antara keduanya. Hal tersebut terjadi karena berbagai faktor antara lain peningkatan Produk Domestik Regional Bruto Kota Pagar Alam pada periode 2013-2017, adanya anggaran yang diberikan oleh pemerintah pusat atas usaha menjemput bola yang dilakukan oleh Ida Fitriati dan sebagainya.

\section{Pengangguran Kota Pagar Alam Tahun 2013-2017}

Perkembangan suatu kota tidak terlepas dari penyerapan tenaga kerja. Sehingga akhirnya akan merangkak pada perekonomian dari suatu daerah. Penyerapan tenaga kerja yang tinggi, otomatis mengurangi tingkat pengangguran. Berikut merupakan data pengangguran yang terdapat di Kota Pagar Alam Tahun 2013-2017:

Tabel 4 : Tingkat Partisipasi Angkatan Kerja dan Pengangguran di Kota Pagar Alam Tahun 2013-2017

\begin{tabular}{ccc}
\hline Tahun & $\begin{array}{c}\text { Tingkat } \\
\text { Partisipasi } \\
\text { Angkatan Kerja } \\
\text { (\%) }\end{array}$ & $\begin{array}{c}\text { Tingkat } \\
\text { Pengangguran } \\
\text { (\%) }\end{array}$ \\
\hline 2013 & 67,25 & 7,04 \\
2014 & 68,59 & 4,81 \\
2015 & 72.98 & 3,53 \\
2016 & 72,98 & 3,53 \\
2017 & 71,99 & 2,57 \\
\hline
\end{tabular}

Sumber: Badan Pusat Statistik Kota Pagar Alam

Tingkat pengguran di Kota Pagar Alam cenderung menurun dari tahun 2013 hingga 2018. Pada tahun 2013, tingkat pengangguran mencapai 7,03 \%, atau jumlah total jiwa dengan jumlah angkatan 
$67,25 \%$. Setiap tahun mengalami penurunan yang cukup signifikan. Hingga pada tahun 2017 penurunan angka pengangguran mencapai angka 2,57\%, atau 1.849 jiwa dengan jumlah angkatan kerja mencapai $71,99 \%$ atau 71.828 jiwa. Pengurangan jumlah pengangguran tersebut sejalan dengan adanya pertumbuhan ekonomi yang terjadi di Kota Pagar Alam. Jika ekonomi Kota Pagar Alam semakin meningkat, maka hal tersebut berdampak pada jumlah angkatan kerja, dan meminimalisir jumlah pengangguran yang ada. Sehingga pemerintah saat itu fokus untuk mengembangkan ekonomi kerakyatan yang ada di Kota Pagar Alam sesuai dengan misi ke dua ibu Ida Fitriati.

Berikut merupakan tabel perbandingan pada masa walikota Djazuli Kuris tahun 2008-2012 di Kota Pagar Alam terkait dengan pengangguran dan angkatan kerja di Kota Pagar Alam:

Tabel 5 Tingkat Partisipasi Angkatan Kerja dan Pengangguran di Kota Pagar Alam Tahun 2010-2012

\begin{tabular}{ccc}
\hline Tahun & $\begin{array}{c}\text { Tingkat } \\
\text { Partisipasi } \\
\text { Angkatan Kerja } \\
\text { (\%) }\end{array}$ & $\begin{array}{c}\text { Tingkat } \\
\text { Pengangguran } \\
\text { (\%) }\end{array}$ \\
\hline 2010 & 67,48 & 9,76 \\
2011 & 70,09 & 6,02 \\
2012 & 71,42 & 3,91 \\
\hline
\end{tabular}

Sumber: Badan Pusat Statistik Kota Pagar Alam

Sehingga dapat dibandingkan bahwa antara pemerintahan tahun 2008-2012 dengan tahun 2013-2018 terus mengalami peninggkatan. Dibuktikan dengan adanya perbandingan antara jumlah angkatan kerja di Kota Pagar Alam pada tahun tersebut. Pada tahun 2010 angkatan kerja Kota Pagar Alam mencapai 78,48\%, dengan tingkat pengangguran mencapai 9,76\%. Pada tahun 2017 jumlah angkatan kerja Kota Pagar Alam mencapai 71,99\%, dengan tingkat pengangguran hanya sekitar $2,57 \%$.

\section{Angka Kemiskinan Tahun 2013-2017}

Perkembangan Kota Pagar Alam juga dipengaruhi dengan jumlah kemiskinan. Beberapa sektor yang mendukung berkurangnya angka kemiskinan antara lain adanya penyerapan jumlah tenaga kerja, pendapatan daerah dan penurunan jumlah pengangguran. Adapun presentase angka kemiskinan di Kota Pagar Alam tahun 20132018 antara lain:

Tabel 6: Presentase Penduduk Miskin di Kota Pagar Alam Tahun 2013-2018

\begin{tabular}{cc}
\hline Tahun & Presentase \\
\hline 2013 & $9,00 \%$ \\
2014 & $8,90 \%$ \\
2015 & $9,64 \%$ \\
2016 & $9,19 \%$ \\
2017 & $8.89 \%$ \\
\hline
\end{tabular}

Sumber: Badan Pusat Statistik Kota Pagar Alam, 2018: 266

Jumlah penduduk miskin di Kota Pagar Alam paling sedikit nomor satu di Sumatera Selatan. Hal tersebut merupakan pencapaian yang sangat luar biasa oleh Kota Pagar Alam. Pada tahun 2013 jumlah penduduk miskin di Kota Pagar Alam mencapai 9.00\%, dan mengalami penurunan pada tahun berikutnya. Namun pada tahun 2015 mengalami peningkatan $0.74 \%$. Peningkatan tersebut terjadi karena pada saat itu terjadi krisis ekonomi di 
seluruh Sumatera Selatan, akibat kebakaran hutan dan kabut asap yang juga berimbas di Kota Pagar Alam yang juga mengalami hal tersebut. Pada tahun berikutnya kembali mengalami penurunan hingga 9.19\%. Pada tahun 2017 menjadi 8.89\% karena banyak dilakukan pelatihan-pelatihan oleh pemerintah kepada masyarakat Kota Pagar Alam. Tujuannya supaya dapat meningkatkan kesejahteraan dari hidup mereka.

Tabel 7 Presentase Penduduk Miskin di Kota Pagar Alam Tahun 2008-2012

\begin{tabular}{cc}
\hline Tahun & Presentase \\
\hline 2008 & $10,23 \%$ \\
2009 & $9,66 \%$ \\
2010 & $9,81 \%$ \\
2011 & $9,24 \%$ \\
2012 & $9,00 \%$ \\
\hline
\end{tabular}

Sumber: Badan Pusat Statistik Kota pagar Alam, 2012: 398

Pada perbandingan kedua tabel tersebut jumlah Penduduk miskin Kota Pagar Alam mengalami penurunan pada setiap tahunnya. Pada tahun 2008 jumlah penduduk miskin Kota Pagar Alam mencapai 10,23\%. Namun pada tahun 2017 mengalami penurunan hingga 8,89\%. Penurunan tersebut tidak terlalu signifikan namun ada pada setiap tahunnya.

Sebenarnya untuk mengetahui perkembangan suatu kota harus bisa bersaing dengan daerah sekitar. Maka dari itu diperlukan perbandingan antara kabupaten atau kota yang ada di Sumatera Selatan. Jumlah penduduk miskin di Kota Pagar Alam mencapai 8,89\% dari seluruh jumlah penduduk. Hal tersebut merupakan kota yang paling sedikit penduduk miskin di Sumatera Selatan. Berbeda dengan Kabupaten Musi Rawas Utara yang penduduk miskinnya mencapai 19,49 \%, dan merupakan kabupaten termiskin di Provinsi Sumatera Selatan. Faktor yang mempengaruhi sedikitnya penduduk miskin di Kota Pagar Alam adalah jumlah penduduk Kota Pagar Alam paling sedikit di Sumatera Selatan. Bersamaan dengan itu pertumbuhan ekonomi di Kota Pagar Alam cenderung stabil dibandingkan dengan wilayah lain di kawasan Sumatera Selatan.

\section{E. Analisa Indeks Pembangunan Manusia Kota Pagar Alam Tahun 2013-2018}

Dalam indeks pembangunan manusia diperlukan adanya perbandingan indeks pembangunan antar kabupaten/kota. Indeks pembangunan manusia merupakan usaha yang dilakukan pemerintah kota untuk meningkatkan kualitas sumber daya manusia di daerah tersebut. Adapun indikator pendukung dari indeks pembangunan manusia adalah indeks pendapatan perkapita, indeks pendidikan (angka melek huruf dan lama sekolah), dan indeks kesehatan (umur dan harapan hidup) (Kemenkes, 2010).

Pendapat lain menyebutkan bahwa indeks pembangunan manusia mempunyai indikator antara lain umur panjang dan sehat, penegtahuan dan standar hidup layak (BPS Kota Pagar Alam, 2018). Tabel tersebut menjelaskan bahwa di Sumatera Selatan indeks pembangunan manusia 
ditetapkan adalah 80.00. Namun setiap kabupaten/kota di Sumatera Selatan belum bisa mencapai target tersebut. Begitu pula Kota Pagar Alam yang indeks pembangunan manusia hanya mencapai $65,96 \%$ yaitu mencapai peringkat ke delapan di Sumatera Selatan (Badan Pusat Statistik Kota Pagar Alam, 2018: 267).

Tabel 7 Indeks Pembangunan Manusia Kota Pagar Alam Tahun 2013-2017

\begin{tabular}{cc}
\hline Tahun & Presentase \\
\hline 2013 & 63,33 \\
2014 & 64,14 \\
2015 & 64,75 \\
2016 & 65,37 \\
2017 & 65,96 \\
\hline
\end{tabular}

Sumber: Badan Pusat Statistik Kota Pagar Alam, 2018: 267

Seharusnya untuk Kota Pagar Alam yang memiliki penduduk miskin yang tergolong sedikit, maka juga harus mempunyai indeks pembangunan manusia yang paling tinggi juga. Namun pada kenyataanya tidak. Hal tersebut disebabkan karena penduduk Kota Pagar Alam kebanyakan mempunyai pola pikir yang sebagian besar belum maju.

Pemerintah kota banyak sekali melakukan penarikan untuk pelatihan bagi masyarakat Kota Pagar Alam agar lebih berkembang. Bahkan hingga di kirim ke luar kota untuk belajar melihat dari daerah lain. Namun setelah itu, mereka masih menetapkan pola yang mereka lakukan sebelumnya (Wawancara Ida Fitriati Tanggal 7 januari 2019 Pukul 14.00).
Tabel 8 Indeks Pembangunan Manusia Kota Pagar Alam Tahun 2008-2012

\begin{tabular}{cc} 
Tahun & Presentase \\
\hline 2008 & 72,16 \\
2009 & 72,48 \\
2010 & 73,19 \\
2011 & 73,51 \\
2012 & 74,15 \\
\hline
\end{tabular}

Sumber: Badan Pusat Statistik Kota Pagar Alam, 2013: 410

Pada kedua tabel tersebut dapat di lihat bahwa indeks pembangunan manusia pada masa walikota Ida Fitriati mengalami penurunan dari periode sebelumnya yaitu tahun 2012. Presentase indeks pembangunan manusia mencapai 74,15\% yang merupakan peringkat 3 Sumatera Selatan. Namun pada tahun 2017 mengalami penurunan yang sangat signifikan yaitu 65,95\%.

\section{F. Evaluasi Pencapaian Proses}

Perkembangan Kota Pagar Alam

Proses perkembangan Kota Pagar Alam tahun 2013-2018 telah tercantum dalam Rencana Pembangunan Jangka Menengah Daerah. Setelah melalui beberapa data yang diambil, sebenarnya proses pembangunan Kota Pagar Alam rata-rata telah mencapai dari target yang telah ditetapkan.

Ada empat indikator yang diambil yaitu perkembangan ekonomi yang dalam hal ini di fokuskan pada Produk Domestik Regional Bruto, data pengangguran, data kemiskinan dan data indeks pembangunan manusia di Kota Pagar Alam pada tahun 2013-2017. Sehingga dari tahun ke tahun Kota Pagar Alam merupakan kota yang 
mempunyai penduduk miskin paling sedikit di Provinsi Sumatera Selatan. Pengangguran yang ada di Kota Pagar Alam selalu menurun setiap tahunnya. Namun Kota Pagar Alam masih memiliki indeks pembangunan manusia $65,98 \%$ yang belum mencapai target dari Provinsi Sumatera Selatan yaitu 80,00. Indeks pembangunan manusia di Kota Pagar Alam masuk peringkat delapan di Sumatera Selatan.

Hal tersebut menunjukan ketidakseimbangan antara indikator satu dengan yang lain. Adapun penyebabnya adalah pemerintah serta satuan kerja perangkat daerah Kota Pagar Alam terlalu fokus pada hasil. Namun dalam pelaksanaannya ada indikator yang dilewatkan.

\section{G. Hambatan Proses Perkembangan Kota Pagar Alam}

Proses perkembangan Kota Pagar Alam merupakan hasil kerja keras dari setiap aspek masyarakat yang ada dan terlibat di dalam Kota Pagar Alam, Pemerintah Kota Pagar Alam, serta satuan kerja perangkat daerah. Sehingga terwujud pembangunan yang berkala di Kota Pagar Alam. Namun, selain dari beberapa dukungan tersebut ada beberapa hambatan yang terjadi dilapangan.

Adapun hambatan tersebut adalah adanya aspek pembangunan yang sulit tercapai meliputi dana, kurangnya dorongan yang terjadi di sebagian masyarakat yang mempunyai pola pikir masih tradisional, kurangnya tenaga ahli pada bidang terkait seperti bidang pertanian dan pariwisata. Sektor unggulan dari Kota pagar Alam adalah pariwisata dan pertanian. Namun pada sektor tersebut masih kurang tenaga ahli yang ahli dibidangnya. Terlalu banyak target dari pemerintah sehingga banyak kegiatan pembangunan yang tidak fokus sehingga yang lain juga tidak dapat (wawancara Ida Fitriati tanggal 7 januari 2019).

Pada satuan kerja terkait digolongkan hambatan tersebut dalam beberapa hambatan proses pencapaian misi sesuai dengan visi yang telah disusun sebelumnya, antara lain:

1. Salah satu pendukung keberhasilan kinerja misi ke satu adalah efektivitas dan efisiensi pelaksanaan program pembangunan pendidikan, kesehatan, pemberdayaan perempuan dan perlindungan anak, keluarga berencana dan keluarga sejahtera, pemuda dan olahraga, perpustakaan, kearsipan, dan sumber daya manusia selama tahun 2013-2018. Sedangkan dalam pelaksanaannya Walikota dan Wakil Walikota Pagar Alam di bantu beberapa dinas terkait dalam pelaksanaan misi satu yaitu Dinas Pendidikan, Dinas Kesehatan, Rumah Sakit Umum Daerah, Badan Keluarga Berencana, Dinas Perpustakaan dan Arsip Daerah, kantor pemuda dan Olahraga, dan Dinas Pekerjaan Umum. Faktor pendukung lain, 
yaitu dukungan masyarakat dalam mewujudkan misi ke satu tersebut, kemampuan aparat dalam meningkatkan pelayanan publik, kemampuan dari satuan kerja perangkat daerah dalam melakukan pelayanan publik, adanya suatu keunggulan dari perangkat satuan terkait dalam perencanaan dan pendanaan basis kerja, adanya kerja sama yang kuat dari setiap satuan kerja didalam pelaksanaan tugasnya. Penghambat dari pencapaian misi satu antara lain adalah padatnya kegiatan dari masing-masing perangkat daerah yang terkait sehingga dalam pelaksanaan poin-poin misi tersebut menjadi tidak fokus, penetapan indikator yang tidak melihat kapasitas yang di miliki oleh Satuan Kerja Perangkat daerah tersebut (Wawancara Dwi Baskoro, tanggal 15 Maret 2019).

2. Beberapa penyebab capaian indikator belum tercapai, diantaranya masih kurangnya kesadaran masyarakat Kota Pagar Alam untuk berpolitik, masyarakat perlu meningkatkan dan ikut berperan serta dalam menjaga ketentraman dan ketertiban Kota Pagar Alam, lapangan pekerjaan yang masih kurang sehingga menyebabkan angka partisipasi kerja dan tingkat pengngguran masih cukup tinggi, serta adanya beberapa peran pemerintah kota menjadi beralih menjadi peran provinsi (Wawancara Yudiansyah, tanggal 15 Maret 2019 pukul 10.00). Faktor yang mendukung dari proses realisasi misi II, yakni adanya dukungan dari masyarakat dalam mewujudkan misi kedua tersebut, adanya program dan target yang di berikan oleh pemerintah pusat kepada satuan kerja perangkat daerah terkait dalam pelaksanaan tugasnya. Adapun faktor penghambat dari proses realisasi misi kedua adalah kesempatan kerja yang kurang yang dimiliki masyarakat Kota Pagar Alam dan pola pikir masyarakat yang masih tradisional.

3. Beberapa hal yang belum tercapai dilaksanakan oleh urusan pertanian, kehutanan dan perdagangan. Beberapa penyebab capaian indikator belum tercapai adalah adanya indikator yang terlalu optimis dan sulit diukur, serta adanya kewenangan pemerintah daerah yang beralih ke pemerintah pusat dalam pelaksanaannya (Pemerintah Kota Pagar Alam, 2018. VII.7-VII.9). Faktor yang menjadi pendukung keberhasilan kinerja misi ketiga adalah adanya kerjasama antara pemerintah daerah, satuan kerja pejabat daerah dan masyarakat Kota Pagar Alam dalam mewujudkan misi ketiga tersebut, dan adanya peran serta dari pemerintah provinsi terkait indikator yang mempunyai keterkaitan. Faktor penghambat pencapaian realisasi dari misi ketiga adalah menajeman pemerintah daerah yang kurang dan juga adanya suatu indikator yang diterapkan 
tidak sesuai dengan keadaan di lapangan (Wawancara Dwi Baskoro, tanggal 15 Maret 2019 pukul 10.00).

4. Beberapa penyebab tidak tercapainya indikator adalah terlalu optimis nilai indikator yang dibuat, sehingga sulit untuk dicapai dan jumlah anggaran yang tidak mencukupi untuk menyelenggarakan festival budaya (Pemerintah Kota Pagara Alam , 2018: VIII.7). Faktor pendukung keberhasilan kinerja misi Keempat adalah adanya kerjasama yang baik antara pemerintah daerah, satuan kerja pejabat daerah terkait, dan masyarakat Kota Pagar Alam. Kemudian adanya usaha-usaha yang dilakukan oleh perangkat terkait dalam melakukan inovasi baru pelaksanaan kepariwisataan. Sedangkan faktor penghambatnya adalah kurang tenaga kerja yang ahli dibidang pariwisata, dan proses pembukaan obyek pariwisata yang memerlukan dana yang cukup besar (Wawancara Dwi baskoro, tanggal 15 Maret 2019 pukul 10.00).

5. Beberapa penyebab tidak tercapainya indikator adalah terlalu optimis nilai indikator yang dibuat, sehingga sulit untuk dicapai dan jumlah indikator yang tidak relevan lagi seperti jumlah warnet terhadap penduduk. Karena adanya kecanggihan teknologi, sehingga jumlah warnet semakin sedikit (Pemerintah Kota Pagar Alam, 2018:IX.12-IX14). Realisasi Misi 5 tersebut berfokus pada bidang pembangunan yang dilaksanakan beberapa bidang yang mendukung seperti Dinas Pekerjaan Umum dan Tata Ruang, Dinas Perhubungan, Kantor Urusan Perumahan Rakyat dan Kawasan Pemungkiman serta Dinas Komunikasi dan Informatika. Dari beberapa dinas dan badan yang terlibat tersebut dapat terbagi menjadi beberapa program. Salah satu pendukung pencapaian misi kelima adalah adanya dukungan masyarakat dalam perwujudan misi kelima cukup baik. Sedangkan faktor penghambat dari berjalannya misi 5 adalah terlalu optimis dalam pembuatan nilai indicator, sehingga sangat sulit untuk dicapai dan jumlah indikator yang tidak relevan.

\section{Penutup}

\section{A. Kesimpulan}

Peran Ida Fitriati dalam perkembangan Kota Pagar Alam ialah sebagai Walikota Pagar Alam. Proses perkembangan tersebut berasal dari visi dan misi yang telah ditetapkannya, sehingga menjadi bahan acuan dalam membawa Kota pagar Alam menjadi kota yang lebih baik dari sebelumnya. Perkembangan ekonomi Kota Pagar Alam meningkat pada setiap tahunnya baik pada Produk Domestik Regional Bruto sampai ke Anggaran Pendapatan dan Belanja Daerah Kota Pagar Alam. Hal tersebut juga mengalami peningkatan jika dibandingkan dengan periode tahun 2008-2017. Angka angkatan 
kerja dan jumlah pengangguran Kota Pagar Alam pada tahun 2017 maju ke arah yang positif. Walaupun hal tersebut tidak terlalu signifikan. Angka kemiskinan Kota Pagar Alam mengalami penurunan pada setiap tahun. Sehingga dalam perkembangannya, Kota Pagar Alam tumbuh menjadi Kota yang memiliki penduduk miskin paling sedikit di Sumatera Selatan. Indeks pembangunan manusia Kota Pagar Alam mengalami kemunduran dibandingkan dengan periode sebelumnya. Juga menduduki peringkat 8 Sumatera Selatan. Padahal Kota Pagar Alam merupakan Kota dengan Penduduk miskin paling sedikit di Sumatera Selatan.

\section{B. Saran}

Berkaitan dengan penelitian yang telah dilakukan, ada beberapa saran yang akan disampaikan:

1. Kepada pemegang kebijakan (pemerintah) agar lebih memfokuskan apa saja yang menjadi prioritas pembangunan daerah. Sehingga mampu manopang seluruh aspek kehidupan masyarakat di Kota Pagar Alam.

2. Kepada pemegang kebijakan agar dapat menyeimbangkan antara keunggulan sedikitnya penduduk miskin di Kota pagar Alam dengan indeks pembangunan manusia.

3. Kepada masyarakat Kota Pagar Alam hendaknya dapat memberikan inovasi penting dalam proses pembangunan Kota Pagar Alam tersebut. Setidaknya pada bidang pencariannya masingmasing.

4. Mahasiswa Pendidikan Sejarah Universitas Sriwijaya agar dapat menjadi referensi dari pembuatan tugas karya ilmiah.

\section{Daftar Pustaka}

Badan Pusat Statistik Kota Pagar Alam. (2013). Pagar Alam dalam Angka 2013. pagar Alam: Badan Pusat Statistik.

Badan Pusat Statisti Kota Pagar Alam. (2014). Pagar Alam dalam Angka 2013. Pagar Alam: Badan Pusat Statistik.

Badan Pusat Statistik Kota Pagar Alam. (2015). Pagar Alam dalam Angka 2013. Pagar Alam: Badan Pusat Statistik.

Badan Pusat Statistik Kota Pagar Alam. (2016). Pagar Alam dalam Angka 2013. Pagar Alam: Badan Pusat Statistik.

Badan Pusat Statistik Kota Pagar Alam. (2017). Pagar Alam dalam Angka 2013. Pagar Alam: Badan Pusat Statistik.

Badan Pusat Statistik Kota Pagar Alam. (2018). Pagar Alam dalam Angka 2013. Pagar Alam: Badan Pusat Statistik.

Badan Pusat Statistik Sumatera Selatan. (2017). Sumatera Selatan dalam Angka 2017. Palembang: Badan Pusat Statistik.

Bungin, Burhan. (2013). Metodologi Penelitian Sosial dan Ekonomi. Jakarta: Kencana.

Claver, Pierre dan Young Robert. (2017). Civis: Patrick Geddes's Theory of City Development. Elsevier: Journal Lansscape and Urban Planing, 166, 37-42. 
Daliman. (2018). Metode Penelitian Sejarah. Yogyakarta: Ombak.

Hanif, Muhammad, dkk. (2011). Peran Serta Perempuan Dalam Pelestarian Kesenian Tayub Di Desa Pesu Kecamatan Maospati Kabupaten Magetan. Agastya: Jurnal Sejarah dan Pembelajarannya, 1, 163-172.

Hanif, Muhammad. (2011). Peranan Wanita Desa Soco Bendo Magetan Dalam Mengatasi Dampak Psikologi Sosial Pasca Madiun Affair 1948 (Studi Sejarah Sosial). Agastya: Jurnal Sejarah dan Pembelajarannya, 1, 63-81.

Hanifah, dkk. (1995). Perkembangan Kabupaten Lahat. Lahat: Pemerintah Kabupaten Lahat.

Hariyono, Paulus. (2007). Sosiologi Kota Untuk Arsitek. Jakarta: PT. Bumi Aksara.

Hartono, Yudi, dkk. (2014). Perkembangan Kota Madiun Sebagai Kota Gadis Tahun 2000-2013. Agastya: Jurnal Sejarah dan Pembelajarannya, 4, 7494.

Irwanto, Dedi dan Sair, Alian. (2014). Metodologi dan Historiografi Sejarah. Yogyakarta: La Iq.

Kartodirjo, Sartono. (1993). Pendekatan Ilmu Sosial dalam Metodologi Sejarah. Jakarta: PT Gramedia Pustaka Utama.

Kusuma, Yori Tirta. (2017). Analisis Perkembangan Wilayah (Studi Kasus Pada Kecamatan Pagelaran dan Kecamatan Pagelaran Utara Kabupaten Pringsewu). Skripsi. Lampung: Fakultas Ilmu Sosial dan Politik Universitas Lampung.

Mahardika, Dewa Made Karang dan Fajri, Ahmadul. (2013). Pengabdian Tak Kenal Lelah Demi Bangsa dan Negara (H. Djazuli Kuris Masa Bakti 2003-2008 dan 2008-2013). Pagar alam: Pemerintah Kota pagar alam.
Moisiu, Aleksander. (2004). Decentralization and the Increased Autonomy in Local Government. Mentor ISUFAJ. Procedia-Social and Behavioral Sciences, 109, 459-463.

Nawawi, Hadari. (2012). Metode Penelitian Bidang Sosial. Yogyakarta: Gadjah Mada University Press.

Nazir, Moh. (1983). Metode Penelitian. Jakarta: Ghalia Indonesia.

Nurcahyo, Abraham. (2016). Relevansi Budaya Patriaki dengan partisipasi Politik dan Keterwakilan Perempuan dalam Parlemen. Agastya: Jurnal Sejarah dan Pembelajarannya, 6, 2534.

Pemerintah Kota Pagar Alam. (2013). Rencana Pembangunan Jangka Menengah Daerah (RPJMD) Kota Pagar Alam Tahun 2013-2018. Kota Pagar Alam: Badan Perencanaan Pembangunan Daerah Kota Pagar Alam.

Pemerintah Kota Pagar Alam. (2017). Draft LKPJ AMJ Kota Pagar Alam Tahun 2013-2018. Kota Pagar Alam: Badan Perencanaan Pembangunan Daerah Kota Pagar Alam.

Praesti, Norfia Eka, dan Habsari, Novi Triana. (2013). Peran Perempuan Dalam Perkembangan Ekonomi Di Kampung Tki (Studi Di Desa Lembah Kecamatan Babadan Kabupaten Ponorogo Tahun 20082013). Agastya: Jurnal Sejarah dan Pembelajarannya, 3, 129-179.

Priyadi, Sugeng. (2012). Metode Penelitian Pendidikan Sejarah. Yogyakarta: Ombak Dua.

Sjamsuddin, Helius. (2007). Metodologi Sejarah. Yogyakarta: Ombak.

Syafiie, Inu Kencana. (2005). Filsafat Politik. Bandung: Penerbit Mandar Maju. 